Scientific Journal Warsaw University of Life Sciences - SGGW

Problems of World Agriculture volume 17 (XXXII), number 4, 2017: 210-217

DOI: 10.22630/PRS.2017.17.4.97

\author{
Katarzyna Lukasiewicz ${ }^{1}$ \\ Warsaw University of Life Sciences - SGGW
}

\title{
Perspectives of Agritourism Development in Poland, Belarus and Ukraine
}

\begin{abstract}
Agritourism is a form of leisure, which is increasingly popular. The aim of the article is to present perspectives on the development of agritourism in three countries: Poland, Belarus and Ukraine. The analysis was based on statistical data and the author's own observations. The article also includes a SWOT analysis. The analysis, own observations and observations indicate that in all three countries agritourism has a chance for development. The analysed countries differ in their tourist potential, infrastructure, landscape values, monuments, but one thing they do - tourists want to visit them.
\end{abstract}

Key words: agritourism, Poland, Belarus, Ukraine, perspective, SWOT analysis

JEL Classification: Z32

\section{Introduction}

Agritourism is a form of leisure that is inextricably linked with countryside and agriculture. The offer is predominantly aimed at people living in cities, who have to cope with noise, haste, polluted environment on a daily basis, and need peace and quiet, appropriate conditions to relax in the great outdoors. People are drawn from cities to rural areas by the nature of this form of leisure and the possibility of interacting with nature, and by the possibility to consume Earth's produce and to learn about regional cuisine or tradition. Agritourism constitutes an additional source of income for agricultural societies; it allows them to use the surplus workforce, improves the rural infrastructure, reinvigorates rural areas. It is conducive to improving the quality of life of people living in rural areas, helps them make investment decision and enrich life in a village. It enables a very important cultural exchange of thoughts, views, ways of life.

In agritourism, special attention should be paid to the accommodation providers' potential, which cannot be explicitly defined, presented in a list and evaluated. It is the way in which hosts (accommodation providers) wish to welcome their guests; how they want to make each stay special, to satisfy the guests and make them return to a given agritouristic farm - it is the strength of such enterprises.

Agritourism is a subject of study of many authors, very popular in the world of science. It also constitutes an important research issue of a cognitive, as well as applicational nature.

\footnotetext{
${ }^{1}$ PhD Eng., Warsaw University of Life Sciences, Faculty of Economic Sciences, Department of Economics and Organization of Enterprises, ul. Nowoursynowska 166, 02-787 Warszawa, e-mail: katarzyna lukasiewicz@sggw.pl; https://orcid.org/0000-0001-9715-3756
} 


\section{Data and methods}

This article attempts to, on the one hand, show the current agritourism development status and, on the other hand, determine perspectives of its development in the future. The objective of the article was to present the perspectives of agritourism development in three countries: Poland, Belarus and Ukraine. The considerations were based on data processing methods, i.e. analysis and synthesis. A SWOT analysis of agritourism development in Poland, Belarus and Ukraine has been prepared for the article. The analysis used data from:

- Central Statistical Office (Poland),

- Statistical Office in Ukraine,

- Statistical Office in Belarus,

- available papers and analyses,

- the Author's own observations conducted in Poland and in Ukraine ${ }^{2}$.

\section{Agritourism: its nature and definition methods}

Agritourism began its large-scale development in mid-1990s. Back then, it constituted an alternative or primary source of income for agricultural families. To date, it can provide a possibility of making money by hosts whose agricultural income is insufficient to provide for their families (Roman, Niedziółka, 2017, p. 19).

There are many definitions of agritourism; Drzewiecki's definition appeared first. According to him, agritourism is a form of leisure in rural areas of an agricultural nature, based on accommodation services, and often also on catering. It constitutes a form of recreational activity related to agricultural farms and their environments: natural, production and services (Drzewiecki, 1995, p. 27).

Agritourism is a part of rural tourism. Its offer consists of a stay at a farm (lodging), which can be connected (depending on conditions) with meals throughout the day, or a possibility of buying fresh products from the farm to prepare meals on one's own. Agritourism also involves borrowing a horse, carriage, sports equipment, organizing sleigh rides, selling handicrafts, etc. It also covers enabling tourists to fish, hunt, collect and dry herbs, fruit and mushrooms, ride on horseback, etc. Provided that it's related to agricultural farms (Wiatrak, 1996, p.35).

J. Sikora's definition is different: Agritourism is a specific type of rural (alternative) tourism, organized by agricultural families using housing and vacation resources of an agricultural farm, and environmental, cultural and infrastructural resources of the village and its region (Sikora, 2012, p. 65).

Agritourism is a sector of the tourism industry, focusing on using natural, sociocultural, cultural, historical, and other resources in a village, and taking advantage of its nature to create a comprehensive touristic product (Belova, Komova, 2011, p. 13-16). A complex touristic product is understood as a set of tangible and intangible assets (goods and services) that constitute a particular objective for its guests.

Czerwiński proposes an interesting take; he states that agritourism is a bridge connecting cities and villages, facilitating establishing closer ties with the rural community,

2 In October 2016, the Author has undergone scientific internship at the National University of Life and Environmental Sciences of Ukraine in Kyiv. 


\section{K. Łukasiewicz}

allowing to explore (guest) and cultivate (host) folk traditions and rural lifestyle, while, for the farms, it is an additional source of income from renting accommodations, feeding tourists, and selling agricultural products (Czerwiński, 2015, p. 193).

Agritourism differs from other forms of tourism by (Mikuta, Żelazna, 2004, p. 48):

- $\quad$ space - a village provides tourists with: freedom, unpolluted environment, clean water, close contact with nature, first-hand exposure to cultural and historical heritage;

- existence of agricultural farms and the rhythm of life and work therein - a farm offers a possibility of accommodation and living together with the family that runs it. It allows contact with animals, participating in farm activities, gives the possibility to eat healthy food;

- characteristic rural life - each region has a unique nature (monuments, folk artists, specific festivities);

- stay costs - tourists can be offered various discounts (helping at the farm in exchange for discounts, unassisted preparation of meals, buying cheaper food).

Another method of defining agritourism splits the meaning of the term agritourism into an objective one, which treats agritourism as a form of entrepreneurship of farmers providing services for tourists, and a subjective one, which describes agritourism from the point of view of its participants, i.e. customers of agritouristic farms (CzerwińskaJaśkiewicz, 2013, p.14). Another approach that also splits the definition of agritourism is presented by Balińska, involving the perspective of supply and demand (Balińska, 2016, p. 102). Thus, from the point of view of tourism supply, agritourism is a form of extraagricultural activity of owners of agricultural or sustainable farms, which consists of equivalent performance of agricultural (production) and touristic functions, and providing tourists and guests with a wide variety of services based on the potential of the farm and its environment. From the point of view of tourism demand, agritourism is spending time at agritouristic farms, enabling us to learn the nature of living and working in a village, experience nature and culture, and perform various forms of leisure.

\section{Agritourism in Poland, Belarus and Ukraine}

By analysing the phenomenon of agritourism as exemplified by the three chosen countries, we can unequivocally state that this activity is growing in each country. We will begin analysing this issue with Poland. Table 1. shows agritouristic accommodations by province in 2015, according to the List of Tourism Facilities kept by commune offices. The number of accommodations and their placement indicate that this form of activity is being particularly developed in certain places in the country. These include the provinces: małopolskie (1273), warmińsko-mazurskie (764), pomorskie (687), dolnośląskie (597). There are also provinces with small numbers of agritouristic accommodations. These include: opolskie (107), lubuskie (123), łódzkie (152), kujawsko-pomorskie (211).

Variation in the amount of accommodations depends on various factors. They primarily include: landscape, cultural and historical qualities, motivation of owners of agricultural farms to undertake entrepreneurial activities.

In Poland, it is difficult to specify a precise number of agritouristic farms. This stems from the fact that their definitions are varied and, at the same time, no statistical studies are 
conducted in this regard. According to the Central Statistical Office, there were 802 agritouristic farms in 2016 (CSO, 2016).

Table 1. Agritouristic accommodations in Poland by province in 2015, according to the List of Tourism Facilities kept by commune offices.

\begin{tabular}{l|rrrr}
\hline \multirow{2}{*}{ List } & \multicolumn{2}{c}{ Agritouristic accommodations } & \multicolumn{2}{c}{ Guest rooms } \\
& Facilities & Beds & Facilities & Beds \\
\hline Total & 7726 & 78808 & 16449 & 236609 \\
Dolnośląskie & 597 & 6463 & 1073 & 12772 \\
Kujawsko-pomorskie & 211 & 2297 & 89 & 1442 \\
Lubelskie & 447 & 3770 & 383 & 5813 \\
Lubuskie & 123 & 1265 & 109 & 1637 \\
Lódzkie & 152 & 1475 & 145 & 2423 \\
Małopolskie & 1273 & 15012 & 2961 & 42808 \\
Mazowieckie & 346 & 3363 & 456 & 5291 \\
Opolskie & 107 & 1093 & 82 & 1290 \\
Podkarpackie & 943 & 8037 & 312 & 3968 \\
Podlaskie & 592 & 5513 & 159 & 2392 \\
Pomorskie & 687 & 7500 & 5512 & 80477 \\
Śląskie & 387 & 4657 & 610 & 10553 \\
Świętokrzyskie & 289 & 2754 & 115 & 1484 \\
Warmińsko-mazurskie & 764 & 7092 & 369 & 4105 \\
Wielkopolskie & 427 & 4536 & 317 & 4474 \\
Zachodniopomorskie & 381 & 3981 & 3757 & 55680 \\
\hline
\end{tabular}

Source: Agriculture and Food Economy, Anthology edited by the Institute of Agricultural and Food Economics, Warsaw, 2016, p. 128

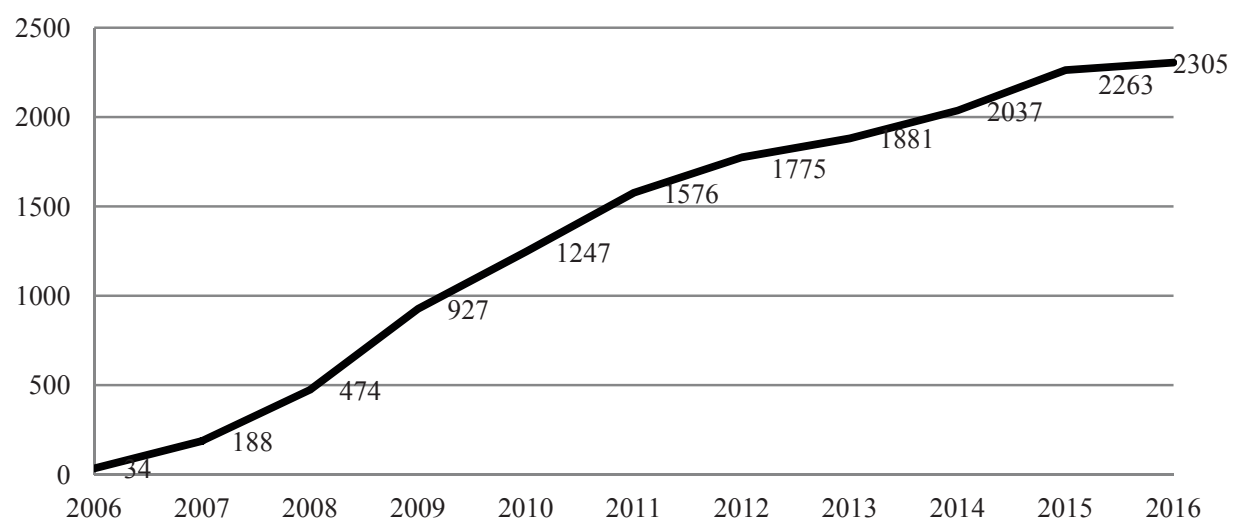

Fig. 1. Number of agritouristic farms in Belarus

Source: own work based on data from belsat.gov.by. Accessed on: 17 November 2017. 


\section{K. Eukasiewicz}

In Belarus, agritourism is being revived. Since 2006, the number of agritouristic farms increased significantly, which is clearly shown on graph 1. It's clear that in the last 10 years their number has increased significantly, from 34 farms in 2006 to 2305 in 2016.

Table 2 presents the number of agritouristic farms by region. It can be clearly seen that this number has increased by several hundred percent. The largest growth is in the Minsk region: from 7 agritouristic farms in 2006 to 613 in 2016, and in the Vitebsk region, correspondingly, from 5 to 612 .

In Belarus agritourism, as a relatively new business, will rise from a promising level to a developed level, assuming a normally functioning legislation. Especially since the interest in rural tourism does not fade on the side of both owners of agritouristic farms and the country's guests and eager Belarusians. (Klicunova, 2014, p. 41).

Table 2. Number of agritouristic farms in Belarus by region

\begin{tabular}{l|rrrrrrrrrrr}
\hline & 2006 & 2007 & 2008 & 2009 & 2010 & 2011 & 2012 & 2013 & 2014 & 2015 & 2016 \\
\hline Brest & 4 & 32 & 75 & 146 & 151 & 178 & 199 & 253 & 296 & 346 & 353 \\
Vitebsk & 5 & 50 & 157 & 273 & 322 & 359 & 401 & 449 & 502 & 605 & 612 \\
Gomel & 5 & 11 & 31 & 60 & 131 & 332 & 358 & 289 & 228 & 196 & 189 \\
Grodno & 11 & 33 & 70 & 156 & 180 & 185 & 229 & 246 & 281 & 303 & 315 \\
Minsk & 7 & 48 & 125 & 214 & 255 & 304 & 412 & 482 & 541 & 597 & 613 \\
Mogilev & 2 & 14 & 16 & 78 & 208 & 218 & 176 & 162 & 189 & 216 & 223 \\
Total & 34 & 188 & 474 & 927 & 1247 & 1576 & 1775 & 1881 & 2037 & 2263 & 2305 \\
\hline
\end{tabular}

Source: own work based on data from belsat.gov.by. Accessed on: 17 November 2017.

Agritourism is also being developed in Ukraine (Zaburanna, 2012, p. 409-413). According to the sources (Lytvyn, Nek, 2013, p. 81-88), main regions with concentration of agritourism are in the Carpathians, Crimea, and in Kyiv and Poltava regions. In 2012, their number equalled 1187 and is still rising. A big role is played by regional and local leisure centres in rural areas. Their tasks focus on providing information about the possibilities of leisure in rural areas, creating a positive image of the region, controlling the quality of touristic services in the region (Marina, 2015, s. 119-122). A significant part of them have been categorized The total categorization in Ukraine included 193 farms from 18 areas, including, with the basic certificate (the lowest): 83 farms, the first certificate: 19 farms, the second certificate: 37 , the third (highest) certificate: 54 (www.greentour.com.ua).

\section{Comparison of agritourism development capabilities in Poland, Belarus and Ukraine}

In order to fully present the development capabilities of agritourism in the selected countries, a SWOT analysis was prepared, specifying strengths, weaknesses, opportunities and threats for the development of agritourism in Poland, Belarus and Ukraine. 
Table 3. SWOT analysis for the development of agritourism in Poland, Belarus and Ukraine

STRENGTHS

\begin{tabular}{|c|c|c|}
\hline Belarus & Poland & Ukraine \\
\hline \multicolumn{3}{|c|}{ Farms situated in touristically attractive regions, large environment and landscape diversity } \\
\hline \multicolumn{3}{|c|}{ Interesting monuments of culture and pieces of folk art } \\
\hline Help in expanding the farm & $\begin{array}{l}\text { Constantly developing transport, social } \\
\text { and economic infrastructure }\end{array}$ & Favourable geopolitical location \\
\hline \multicolumn{2}{|c|}{ Clean natural environment } & Ukrainian cuisine \\
\hline Relatively simple visa rules & \multicolumn{2}{|c|}{ Increased interest in regional culture } \\
\hline \multicolumn{3}{|c|}{ Development of rural areas and renovation of villages } \\
\hline $\begin{array}{l}\text { Growing entrepreneurship among people } \\
\text { living in rural areas }\end{array}$ & $\begin{array}{l}\text { Dynamically growing accommodation } \\
\text { services }\end{array}$ & $\begin{array}{l}\text { Possibilities of development of many } \\
\text { forms of tourism }\end{array}$ \\
\hline $\begin{array}{l}\text { Possibility of taking advantage of forest } \\
\text { and water resources (country-wide) }\end{array}$ & $\begin{array}{l}\text { Quality of accommodation services in } \\
\text { line with global standards }\end{array}$ & Historical and cognitive value of the area \\
\hline \multirow{2}{*}{$\begin{array}{l}\text { Possibility of obtaining a low-interest } \\
\text { loan }\end{array}$} & $\begin{array}{l}\text { State policy fostering the growth of } \\
\text { small enterprises and EU help }\end{array}$ & Significant resources of the workforce \\
\hline & $\begin{array}{l}\text { Openness to change among people living } \\
\text { in rural areas }\end{array}$ & \multirow{2}{*}{ Resources of investment areas } \\
\hline \multirow{2}{*}{$\begin{array}{l}\text { Rich cultural heritage (numerous } \\
\text { monuments, archaeological sites, } \\
\text { cultivating folk traditions) }\end{array}$} & $\begin{array}{c}\text { Appropriate education of people living } \\
\text { in rural areas }\end{array}$ & \\
\hline & $\begin{array}{l}\text { Possibility of joining agritouristic } \\
\text { associations }\end{array}$ & Good soil conditions \\
\hline \multirow{2}{*}{$\begin{array}{l}\text { Very good soil and water conditions and } \\
\text { climate for the development of } \\
\text { agriculture }\end{array}$} & $\begin{array}{l}\text { Increasingly better awareness of the } \\
\text { necessity to categorize rural } \\
\text { accommodation services }\end{array}$ & \multirow{2}{*}{ Rich cultural heritage } \\
\hline & $\begin{array}{l}\text { Simple procedure for establishing an } \\
\text { agritouristic farm }\end{array}$ & \\
\hline \multicolumn{3}{|l|}{ WEAKNESSES } \\
\hline Belarus & Poland & Ukraine \\
\hline $\begin{array}{l}\text { Focus on agritouristic product only on } \\
\text { the country level }\end{array}$ & \multicolumn{2}{|c|}{ Insufficient level of tourism infrastructure in rural areas } \\
\hline No agritouristic associations & $\begin{array}{c}\text { Increasingly large number of people } \\
\text { outside agriculture decide to run a } \\
\text { tourism business }\end{array}$ & Slow investment speed \\
\hline Partial depopulation of villages & $\begin{array}{l}\text { Slightly detrimental demographic } \\
\text { situation in the country }\end{array}$ & Tourism is not financed by the state \\
\hline Complex visa system & $\begin{array}{l}\text { Insufficient experience of } \\
\text { accommodation providers }\end{array}$ & Low development level of IT \\
\hline \multicolumn{2}{|c|}{ Weak promotion and marketing, both domestic and international } & \multirow{2}{*}{$\begin{array}{l}\text { Unfavourable impact of political and } \\
\text { economic conditions }\end{array}$} \\
\hline & Poor acquisition of EU funds & \\
\hline Low development level of IT & Not all farms belong to associations & $\begin{array}{l}\text { Large disproportion between the price } \\
\text { and the quality of service }\end{array}$ \\
\hline \multicolumn{3}{|c|}{ Uneven development of rural areas on the national level } \\
\hline \multicolumn{3}{|c|}{ Poor knowledge of foreign languages among accommodation providers } \\
\hline \multicolumn{3}{|c|}{ Still insufficient desire to care about service quality (categorization) } \\
\hline \multicolumn{3}{|c|}{ Insufficient use of accommodations outside the season } \\
\hline \multicolumn{3}{|c|}{ High level of unemployment in rural areas } \\
\hline \multicolumn{3}{|c|}{ No openness to disabled tourists } \\
\hline \multicolumn{3}{|c|}{ Insufficient qualifications to run such business } \\
\hline \multicolumn{3}{|l|}{ OPPORTUNITIES } \\
\hline Belarus & Poland & Ukraine \\
\hline \multicolumn{3}{|c|}{ Rapid development of technical, social, economic and tourism infrastructure } \\
\hline \multicolumn{3}{|c|}{ Ability to receive additional income from selling farm produce } \\
\hline \multicolumn{3}{|c|}{ Preserving rural heritage (traditions, culture, craftsmanship) } \\
\hline \multicolumn{3}{|c|}{ Ability to expand the offer } \\
\hline & Ability to improve the offer (benchmarking & \\
\hline Increased & terest of city dwellers in the offer of agrito & ism farms \\
\hline & Ability to develop many forms of tourism & \\
\hline $\begin{array}{c}\text { Investments in expanding tourism } \\
\text { business }\end{array}$ & $\begin{array}{c}\text { Creation of many complex rural tourism } \\
\text { products (thematic villages) }\end{array}$ & Increased number of tourist trails \\
\hline Reduction in & nemployment & \\
\hline $\begin{array}{l}\text { The possibility of obtaining external } \\
\text { funds for the development of tourism }\end{array}$ & $\begin{array}{l}\text { New trends in rural and agri-tourism } \\
\text { (e.g. herbalism, health tourism) }\end{array}$ & $\begin{array}{l}\text { Using the Internet as a source of sales, } \\
\text { promotion and distribution of the offer }\end{array}$ \\
\hline
\end{tabular}




\begin{tabular}{|c|c|c|}
\hline Belarus & Poland & Ukraine \\
\hline Low demand for agritouristic products & $\begin{array}{c}\text { Lack of faith in abilities to run an } \\
\text { agritourism farm, despite the existing } \\
\text { potential }\end{array}$ & $\begin{array}{l}\text { Unfavourable economic and political } \\
\text { situation }\end{array}$ \\
\hline $\begin{array}{l}\text { Reluctance of residents towards } \\
\text { innovative ideas }\end{array}$ & $\begin{array}{l}\text { Competition from the tourist side } \\
\text { regional centers }\end{array}$ & $\begin{array}{l}\text { Increased price for services that is } \\
\text { inadequate to the quality decreases } \\
\text { demand }\end{array}$ \\
\hline Marazm of the local community & $\begin{array}{c}\text { Young emigrating } \\
\text { and educated residents }\end{array}$ & $\begin{array}{l}\text { Insufficient number of leisure offers for } \\
\text { low-income people }\end{array}$ \\
\hline Low quality of touristic products & $\begin{array}{c}\text { Increase in the popularity of forms of } \\
\text { tourist activities interfering with the } \\
\text { environment }\end{array}$ & Low quality of touristic products \\
\hline \multicolumn{3}{|c|}{ Poor creativity and innovativeness in action } \\
\hline \multicolumn{3}{|c|}{ Increase in competitiveness through the availability of better offers } \\
\hline \multicolumn{3}{|c|}{ Relatively high costs related to maintaining appropriate standards } \\
\hline \multicolumn{3}{|c|}{ Difficult financial and political situation } \\
\hline \multicolumn{3}{|c|}{ Threat to the natural environment by tourist interference } \\
\hline
\end{tabular}

\section{Summary}

The article presents the current status and agritourism development capabilities in Poland, Belarus and Ukraine. The paper uses statistical data, as well as a SWOT analysis, which enables us to easily formulate conclusions.

In Poland, agritourism has great development chances, because it constitutes an additional source of income, gives the possibility of using already owned resources, reinvigorates rural areas, "opens" native citizens through tourists to new cultures, teaches them acceptance of tourists on their territory and, through new relationships, opens to the world.

In the future this form of activity will develop if:

1. Activities will be focused on building partnerships, large-scale cooperation;

2. Care for the quality of the services provided will be a priority which will contribute to greater opportunity for foreign guests to be interested in the offer;

3. The councilors will pay more attention to the use of programs and assistance that is offered in the country (PROW, Funds);

4. Accommodation providers will meet the market's expectations and start specializing, for example, in the development of health tourism - currently very popular - through the production of healthy, organic food, preparations, cosmetics, aromatherapy, hippotherapy and others;

5. The councilors will pay attention to an important group of recipients, such as older people, for whom the offer should be tailored to their needs.

In Belarus, agritourism has begun to revive in recent years. Everything is possible thanks to beneficial loan conditions, possibility of taking advantage of already owned potential, obtaining additional sources of income, which reduces unemployment. For further dynamic development, farmers need to:

1. Pay attention to the basic recipient which is the domestic customer;

2. Ensure continuous education for people doing agritourism activities, which will strengthen their potential and contribute to greater openness to tourists;

3. To create information centers in the field of agritourism;

4. Take care to improve the quality of services offered that will contribute to interest from foreign tourists. 
In Ukraine, agritourism is also capable of being developed. Despite difficulties resulting from political conditions, it allows farmers to generate income, provides jobs, develops people living in rural areas. For this growth to continue, farmers need to:

5. Pay attention to the basic group of consumers: residents of industrial centers, indigenous inhabitants of cities, lovers of Ukrainian folk traditions, people of medium and low wealth;

6. Include local authorities in supporting this form of activity;

7. Promote this form of tourism;

8. Ensure the quality and categorization of the services provided;

9. Encourage cooperation in the development of agritourism.

\section{Literature}

Balińska, A. (25016). Znaczenie turystyki w rozwoju gmin wiejskich na przykładzie obszarów peryferyjnych wschodniego pogranicza Polski, Wydawnictwo SGGW, Warszawa

Belova, M.A., Komova, O.C. (2011). Praktika formirowania agroturistskogo produkta, Eko i agro-turizm: perspektivy razwitia na lokalnych teritoriach. Materialy III Mezhdunarodnoj nauczno-prakticzeskoj konfederatsji, RIO Bargy, 13-16.

Czerwińska-Jaśkiewicz, M. (2013). Marketing w agroturystyce, Wydawnictwo Difin, Warszawa.

Czerwiński, J. (2015). Podstawy turystyki, Wydawnictwo CeDeWu, Warszawa.

Drzewiecki, M. (1995). Agroturystyka, Instytut Wydawniczy Świadectwo, Bydgoszcz.

Klicunova, V. (2014). Selskij turizm Bełarusi: ustoki i perspektivy, Bełarus w mirie.

Lytvyn, I.V., Nek, M.O. (2013). Problemi ta perspektivy razvitky siskogo zelenogo turismu v regioni. Regionalna Ekonomika, 2(68), 81-88.

Maryna, O.-M.V. (2015). Silskij turyzm jak skladova strategi ekonomicznoj polityki region. Naukowij Bicnik Uzhgorowskogo Universitetu, Seria Ekonomika, 45(3), 119-122.

Mikuta, B., Żelazna, K. (2004). Organizacja ruchu turystycznego na wsi, Wydawnictwo A-B, Warszawa.

Rolnictwo i gospodarka żywnościowa w Polsce (2016). Praca zbiorowa pod redakcją IERiGŻ, Warszawa.

Roman, M., Niedziółka, A. (2017). Agroturystyka jako forma przedsiębiorczości na obszarach wiejskich, Wyd. SGGW, Warszawa.

Sikora, J. (2012). Agroturystyka. Przedsiębiorczość na obszarach wiejskich, Wydawnictwo C. H. Beck, Warszawa.

Wiatrak, A.P. (1996). Wpływ agroturystyki na zagospodarowanie obszarów wiejskich. Zagadnienia Ekonomiki Rolnej, 1, 34-46.

www.greentour.com.ua

www.karpaty.info

www.navkolosvitu.com.ua

www.ruraltourism.com.ua

Zaburanna, L. (2012). Turistichna pidpriemnicka dialalnost w agrarnej sferi: teoria, organizacja, Institut Agrarnej Ekonomiki, Kyiv. 